\title{
THE ROLE OF ODONATE NYMPHS IN ECOFRIENDLY CONTROL OF MOSQUITOES AND SENSITIVITY OF ODONATE NYMPHS TO INORGANIC NUTRIENT POLLUTANTS
}

\author{
ILAHI, $\mathrm{I} .{ }^{*}$ - YOUSAFZAI, A. M. ${ }^{2}-$ ATTAULlaH, M. ${ }^{1}-$ HAQ, T. U. ${ }^{3}-$ ALI, H. ${ }^{1}-$ RAHIM, A. ${ }^{1}-$ \\ SAJAD, MA. ${ }^{2}$ - NAJEEB, S. ${ }^{1}-$ ZAMAN, S. ${ }^{4}-$ UllaH, S. ${ }^{4}-$ AHMAD, A. ${ }^{1}-$ BEGUM, ${ }^{1}{ }^{1}-$ WAQAS $^{1}-$ \\ BIBI, H. ${ }^{1}-$ HUSSAIN, S. $^{1}-$ AHMAD, B. ${ }^{1}$ \\ ${ }^{1}$ Department of Zoology, University of Malakand, Chakdara, Dir Lower, Khyber Pakhtunkhwa, \\ Pakistan \\ ${ }^{2}$ Department of Zoology, Islamia College Peshawar, Peshawar, Khyber Pakhtunkhwa, Pakistan \\ ${ }^{3}$ Department of Biotechnology, University of Malakand, Chakdara, Dir Lower, Khyber \\ Pakhtunkhwa, Pakistan \\ ${ }^{4}$ Department of Botany, University of Malakand, Chakdara, Dir Lower, Khyber Pakhtunkhwa, \\ Pakistan \\ *Corresponding author \\ e-mail:ikramilahi@uom.edu.pk \\ (Received 27 ${ }^{\text {th }}$ Oct 2018; accepted $25^{\text {th }}$ Jan 2019)
}

\begin{abstract}
During the present research, the predatory efficiency of nymphs of six coexisting odonate species i.e., I. elegans, T. aurora, P. flavescens, L. fulva, S. decoloratum and C. servilia was studied by using the $3^{\text {rd }}$ instar larvae of $C x$. quinquefasciatus as prey. Among the odonate species, there was observed variation in the daily feeding rate. The highest number of mosquito larvae was ingested by the $P$. flavescens nymph ( $47.0 \pm 5.1$ mosquito larvae/day). The predation performance of the odonate nymph was also compared between the day and night times. The feeding rate of nymphs of most odonate species was significantly higher during the daytime as compared to night-time $(\mathrm{P} \leq 0.05)$. During the present research, feeing rates of odonate nymphs on $C x$. quinquefasciatus $3^{\text {rd }}$ instar larvae were also studied under varied condition of prey and predator density and water volume. Feeding rate of nymphs of each odonate species was positively correlated with increase in predator and prey density but was negatively correlated with increase in water volume. During the present research, odonate nymphs i.e., I. elegans, T. aurora and $P$. flavescens were exposed to various concentration of $\mathrm{NH}_{4}^{+}$and $\mathrm{NO}_{3}{ }^{-}$in the laboratory for seven days. Nymph of $P$. flavescens species was found least sensitive to both, $\mathrm{NH}_{4}{ }^{+}$and $\mathrm{NO}_{3}{ }^{-}$. From the findings of the present research it was concluded that $P$. flavescens species is more efficient predator of Cx. quinquefasciatus $3^{\text {rd }}$ instar larvae and is highly resistant to increasing water level of $\mathrm{NH}_{4}{ }^{+}$and $\mathrm{NO}_{3}$.

Keywords: damselfly, dragonfly, predation, feeding rate, ammonium, nitrate
\end{abstract}

\section{Introduction}

Control of mosquitoes is mostly practiced by using conventional synthetic chemical insecticides such as organochlorine and organophosphate compounds (Ghosh et al., 2012). The frequent application of synthetic chemical insecticides has caused the development of insecticide resistance in insect pests, contamination of the environment, and adverse effects on non-target organisms (Lee et al., 2001). There is the requirement of adopting environment friendly approaches for the control of mosquito population (Ghosh et al., 2012). Biological control is the application of living organisms that can be used as control agents against insect pests. Several living organisms can act as biological control agents against mosquitoes such as bacteria (Phillips, 2001), plants 
(Ajaegbu et al., 2016), protozoans (Das et al., 2016), larvivorous fish (Walton, 2007) and predatory insects (Mandal et al., 2008).

Predators of mosquito larvae can play important role in regulation of mosquito population (Knight et al., 2004). They not only attack on mosquito larvae but also kill and eat several other co-existing organisms however the presence of alternate preys has no negative influence on the role of predators in regulation of mosquito larval population (Stav et al., 2005). The natural predators that can play role in regulation of mosquito larval population include some larvivorous fish (Chandra et al., 2008), some aquatic bugs (Saha et al., 2007), tadpole shrimps (Su and Mulla, 2002), diving beetles (Lundkvist et al., 2003), Toxorhynchites mosquito larvae (Kumar and Hwang, 2006) and odonate nymphs (Damselfly and dragonfly) (Chatterjee et al., 2007).

Odonate nymphs are important voracious predators and they capture their prey such as mosquito larvae and other smaller aquatic invertebrates and even larvae of fish and amphibians with the help of specialized protractible labium (Boyd, 2005). These nymphs can play important role in the regulation of mosquito population (Din et al., 2013). Due to predatory role against mosquito larvae, they have gained attention for their use in ecofriendly control of mosquitoes (Mitra, 2006). To the best of author knowledge, very few studies have been conducted on the predatory ability of odonate nymphs against mosquito larvae (Mandal et al., 2008; Akram and Ali-Khan, 2016). During the present study, the predatory ability of one species of damselfly (order Odonata, sub order Zygoptera) i.e., Ischnura elegans (Vander Linden, 1820) and five species of dragonfly (order Odonata, sub order Anisoptera) i.e., Trithemis aurora (Burmeister, 1839), Pantala flavescens (Fabricius, 1798), Libellula fulva (Muller, 1764), Sympetrum decoloratum (Selys, 1884) and Crocothemis servilia (Drury, 1770) were studied against Culex quinquefasciatus larvae under laboratory conditions during the day and night times. The predatory ability of odonate nymphs under varied conditions of prey and predator density and water volume were also studied.

Odonate nymphs that share the aquatic habitat with mosquito larvae, face increasing environmental pressure due to increasing urbanization and human activities. Ammonium and nitrate are the important nutrient pollutants and their levels in surface water are increasing (Rabalais, 2002; Du et al., 2017). Ammonium, nitrate and other ionic forms of inorganic nitrogen enter the surface water both from natural sources and anthropogenic sources (Wetzel, 2001; Rabalais, 2002; Du et al., 2017). Increased level of different forms of inorganic nitrogen in water is toxic to fresh water invertebrates, fishes and amphibian (Hickey and Vickers, 1994; Camargo et al., 2005). Odonate nymphs are sensitive to environmental pollutants (Clark and Samways, 1996). To the best of author knowledge, a single study has been reported on the effect of ammonium on odonate nymphs such as Erythromma najas, Lestes sponsa and Sympetrum flaveolum (Beketov, 2002). Dida et al. (2015) recently studied the diversity of predators and mosquito larval habitats and the range of their adaptive capacity to water physicochemical parameters along the Mara River. It was concluded that the invasion of aquatic habitats by the predators of mosquito larvae is driven by the presence of mosquito larvae and the water physico-chemical characteristics. It was suggested that understanding the biotic and abiotic characteristics of aquatic habitats that favor the cooccurrence of mosquito larvae and predators may contribute to the effective control of mosquito borne diseases. During the present study, the sensitivity of nymphs of three odonate species i.e., Ischnura elegans, Trithemis aurora and Pantala flavescens to ammonium and nitrate was studied. 
The present research aimed to explore the comparative predatory efficacy of different odonate nymphs against mosquito larvae and the predatory ability of odonate nymphs under varied conditions of prey and predator density and water volume. The present research also aimed to determine the sensitivity of odonate nymphs to inorganic nutrient pollutants i.e., ammonium and nitrate.

\section{Materials and methods}

\section{Laboratory rearing of $C x$. quinquefasciatus}

Laboratory colonies of $C x$. quinquefasciatus were maintained during April 2017 (max temperature $29^{\circ} \mathrm{C}$ ) and September 2017 (max temperature $31^{\circ} \mathrm{C}$ ). Larvae of $C x$. quinquefasciatus were collected by using a rectangular plastic dipper $(38 \mathrm{~cm}$ length, $28 \mathrm{~cm}$ width and $6.5 \mathrm{~cm}$ height) from a ditch containing stagnant water at the campus of university of Malakand, Chakdara, Dir Lower, Khyber Pakhtunkhwa, Pakistan. The larvae were brought in $700 \mathrm{ml}$ plastic containers with water from the collection site to the laboratory at the University of Malakand and reared for establishing a colony. The larvae were provided with larval food comprising of dog biscuit and dry yeast powder in the ratio of $3: 2$. The pupae emerged were transferred to a $500 \mathrm{ml}$ plastic jar containing $300 \mathrm{ml}$ non-chlorinated tap water and placed in mosquito cage $(45 \mathrm{~cm} \times$ $45 \mathrm{~cm} \times 45 \mathrm{~cm}$ ). The adults emerged were fed with carbohydrate food by providing cotton pad soaked in $10 \%$ sucrose solution. The female adult mosquitoes laid eggs in the jar containing water inside the cage. The eggs hatched into larvae, thus larvae of each instars were available for experiments. For confirmation of species proper literature was used for identification of both larvae and adults (Harbach, 1988).

\section{Collection and identification of odonate nymphs}

Several puddles on the bank of River swat near the campus of University of Malakand, were visited during April and May 2017 and September 2017 for collection of damselfly and dragonfly nymphs. Damselfly and dragonfly nymphs of 8 to 10 instars were collected by using a rectangular plastic dipper $(38 \mathrm{~cm}$ length, $28 \mathrm{~cm}$ width and $6.5 \mathrm{~cm}$ height) on the bank of River swat near the campus of University of Malakand, during April 2017, and September 2017. The nymphs were transported in plastic jars containing water of the collection site to the laboratory at University of Malakand within $1 \mathrm{~h}$ of capture. In the laboratory damselfly and dragonfly nymphs were separately maintained in small fish aquaria $(45 \mathrm{~cm}$ length, $40 \mathrm{~cm}$ width and $40 \mathrm{~cm}$ height) containing water brought from the collection site in large plastic bottles. Aquaria were receiving solar illumination through windows and oxygenated by using air pumps. Few strings of aquatic plants brought from the collection site were also added to the aquaria which provided clinging sites for the nymphs. Before conducting experiments, the nymphs were fed with dried yeast powder and mosquito larvae. The specimens were identified to the species level with the help of literature (Gardner, 1960; Yousuf et al., 1996; Anjum, 1997; Mitra, 2002; Din et al., 2013). During the identification of odonate nymph, help was also taken from the literature and unpublished documents provided by Dr. Ahmad Zia (personal communication), Senior Scientific Officer and Taxonomist in the Insect National Museum at National Agricultural Research Council (NARC), Islamabad, Pakistan. During April 2017 collection of odonate nymphs, one species of damselflies namely Ischnura elegans and two species of dragonflies namely Trithemis 
aurora and Pantala flavescens were identified. During September 2017 collection, dragonfly nymphs of Libellula fulva, Sympetrum decoloratum and Crocothemis servilia were identified and found in sufficient number; therefore, experiments were conducted on nymphs of these genera. All the odonate species identified and studied are shown in Figure 1.

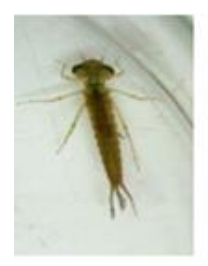

A

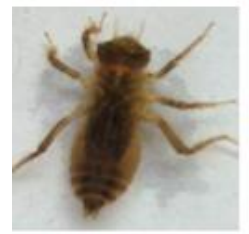

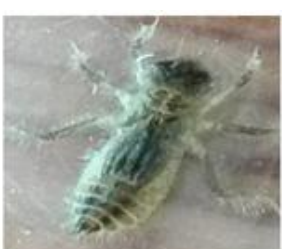

B

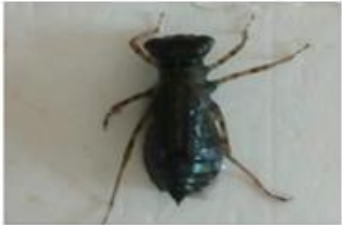

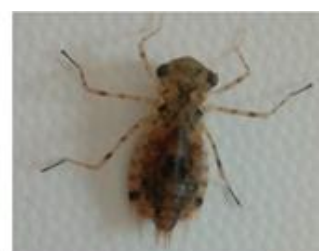

c

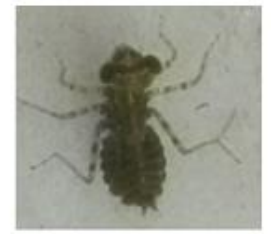

Figure 1. Pictures of nymphs of different odonate species collected and used during the present research. A - Ischnura elegans, $B$ - Trithemis aurora, $C$ - Pantala flavescens, $D$ - Libellula fulva, E - Sympetrum decoloratum, $F$ - Crocothemis servilia

\section{4-h feeding rate of donate nymphs during April, 2017}

During April 2017, three nymphs of three odonate species (one nymph of each Species) i.e., Ischnura elegans, Trithemis aurora and Pantala flavescens, were placed separately into three labelled $1000 \mathrm{ml}$ plastic jars each jar was containing $700 \mathrm{ml}$ sieved water of collection site. To each container $803^{\text {rd }}$ instar larvae were added. Twelve replicates were run for each predator species. The experiments were started at 05:00 h of Pakistan standard time and the results were checked next day at 05:00 h (after $24 \mathrm{~h}$ ). The number of larvae consumed by each predator species was counted after $24 \mathrm{~h}$.

\section{4-h feeding rate of donate nymphs during September, 2017}

During September 2017, the feeding efficiencies of dragonfly nymphs of L. fulva, S. decoloratum and $C$. servilia on $3^{\text {rd }}$ instar larvae of Culex quinquefasciatus were compared. These three dragonfly nymphs were placed separately into three labelled $1000 \mathrm{ml}$ plastic jars each containing $700 \mathrm{ml}$ sieved water of collection site. To each container $503^{\text {rd }}$ instar larvae were added. Six replicates were run for each predator species. The experiments were started at 07:00 h of Pakistan standard time and the results were checked next day at 07:00 h (after $24 \mathrm{~h}$ ). The number of larvae consumed by each predator species was counted after $24 \mathrm{~h}$.

\section{Feeding rate of odonate nymphs during light and dark phases in April, 2017}

During April 2017, the feeding rates of Ischnura elegans, Trithemis aurora and Pantala flavescens on $3^{\text {rd }}$ instar larvae of $C x$. quinquefasciatus were studied during the light (day time) and dark (night time) phases. The durations of light phase (5:00 to 
19:00 h) was $14 \mathrm{~h}$ and dark phase (19:00 to 5:00 h) was $10 \mathrm{~h}$. Per hour feeding rate was calculated. One nymph each of Ischnura elegans, Trithemis aurora and Pantala flavescens, were placed separately into three labelled 1000-ml plastic jars each containing $700 \mathrm{ml}$ sieved water of collection site. Eighty $3^{\text {rd }}$ instar larvae of $C x$. quinquefasciatus were added to each jar at 05:00 h (sunrise time) and the number of larvae consumed by each nymph was noted at 19:00 h (sunset time). The laboratory was receiving sufficient light during the day through windows. To determine the feeding rate of nymphs during the dark phase, $803^{\text {rd }}$ instar larvae of $C x$. quinquefasciatus were added to each jar at 19:00 $\mathrm{h}$ (sunset time) and the number of larvae consumed by each nymph was noted at next 05:00 h (sunrise time). The experiment was run in 12 replicates.

\section{Feeding rate of odonate nymphs during light and dark phases in September, 2017}

During September 2017 study, three nymphs of three dragonfly species i.e., Libellula, Sympetrum and C. servilia were placed separately into three labelled $700 \mathrm{ml}$ plastic jars (one nymph of one odonate species/jar) each containing $400 \mathrm{ml}$ sieved water of collection site. Fifty $3^{\text {rd }}$ instar larvae of $C x$. quinquefasciatus were added to each jar at the morning (06:00 h, Pakistan standard time). The duration of light phase (6:00 $\mathrm{h}$ to 18:09 h) and dark phase (18:09 to 6:00 h) was $12 \mathrm{~h}$ each. Therefore the 12 -h feeding rate of dragonfly nymphs was compared between light and dark phases.

\section{Feeding pattern of odonate nymphs after every 3 h interval in day and night}

The feeding activities of dragonfly nymphs were also noted after every $3 \mathrm{~h}$ for $24 \mathrm{~h}$ (6:00-9:00 h, 9:00-12:00 h, 12:00-15:00 h, 15:00-18:00 h, 18:00-21:00 h, 21:0024:00 h, 24:00-3:00 h, 3:00-6:00 h Pakistan standard time). Sieved water of collection site was utilized for experiment.

\section{Feeding rate under varied condition of predator density, water volume and prey density}

The predation of damselfly and dragonfly nymphs on $3^{\text {rd }}$ instar $C x$. quinquefasciatus larvae with variation in predator density, water volume and prey density were evaluated during April 2017. For each odonate nymph, six 4 L plastic jars were arranged with varied predator density, water volume and prey density. The experiment for each predator species was conducted on three different dates and in triplicate. The six combinations for each odonate species are shown in Table 1.

Table 1. Various combinations of predator density, water volume and prey density

\begin{tabular}{c|c}
\hline S. No. of combinations & Combinations \\
\hline 1 & 1 predator, 1 L and 50 Prey \\
2 & 1 predator, 2L and 50 Prey \\
3 & 1 predator, 1 Land 100 Prey \\
4 & 2 predators, 1 L and 50 Prey \\
5 & 2 predators, 2 L and 50 Prey \\
6 & 2 predators, 1 Land 100 Prey \\
\hline
\end{tabular}


The number of larvae consumed was noted after $24 \mathrm{~h}$. The predation performance data obtained during September 2017 experiments have been presented separately from the data obtained during April 2017 experiments due to differences in timing and number of replicas.

\section{Sensitivity of odonate nymphs to inorganic nutrient pollutants}

During the present research, the sensitivity of nymphs of I. elegans, T. aurora and $P$. flavescens to various concentrations of inorganic nutrient pollutants i.e., ammonium $\left(\mathrm{NH}_{4}{ }^{+}\right)$and nitrate $\left(\mathrm{NO}_{3}{ }^{-}\right)$was investigated. These nymphs were exposed to various concentrations of $\mathrm{NH}_{4}{ }^{+}$and $\mathrm{NO}_{3}{ }^{-}$in water.

\section{Sensitivity of odonate nymphs to Ammonium}

Stock solution of $\mathrm{NH}_{4}{ }^{+}$was prepared by dissolving ammonium chloride $\left(\mathrm{NH}_{4} \mathrm{Cl}\right)$ in non-chlorinated tap water. The molecular weight of $\mathrm{NH}_{4} \mathrm{Cl}$ is $53.5 \mathrm{~g}$ which contains $18 \mathrm{~g}$ of $\mathrm{NH}_{4}{ }^{+} .2 .9 \mathrm{~g}$ of $\mathrm{NH}_{4} \mathrm{Cl}$ was required for preparation of $1000 \mathrm{ml} \mathrm{NH}_{4}{ }^{+}$solution of $1000 \mathrm{ppm}$. From this stock solution, testing solutions of different concentrations of $\mathrm{NH}_{4}{ }^{+}$were prepared by applying the dilution equation $\mathrm{C} 1 \mathrm{~V} 1=\mathrm{C} 2 \mathrm{~V} 2$.

According to the WHO (2006) standards for wastewater reuse in the Eastern Mediterranean Region, the maximum permissible concentration of NH4 in effluents for reuse in agricultural irrigation is $5 \mathrm{ppm}$. Therefore, during the present research, the minimum concentration of $\mathrm{NH}_{4}{ }^{+}$to which odonate nymphs were exposed was $5 \mathrm{ppm}$. Thus, I. elegans, T. aurora and $P$. flavescens were initially exposed to testing solutions of 5, 10, 25, 50 and $100 \mathrm{ppm}$ concentrations of $\mathrm{NH}_{4}{ }^{+}$in $400 \mathrm{ml}$ polyethylene containers for finding concentration range to be used for determining the LC50 values. The ecological effects test guidelines of Environmental Protection Agency, USA (US EPA, 1996) were followed with some modifications for determining the concentration range. Volume of testing solution in each polyethylene container was $250 \mathrm{ml}$. A $400 \mathrm{ml}$ polyethylene control container containing $250 \mathrm{ml}$ non-chlorinated tap water was also kept. Nymphs of each species were exposed individually in containers to avoid cannibalism. Due to individual placement, limited laboratory space and limited availability of nymphs, the method of Hardersen and Wratten (1996) was followed. The detail is as under: six intact $8^{\text {th }}$ to $10^{\text {th }}$ instar nymphs of each species were placed in six plastic containers (five $\mathrm{NH}_{4}{ }^{+}$concentrations and one control). In short, 18 containers were arranged for the nymphs of three odonate species, six for each species. Experiment was run in five replicates. The period of exposure was 7 days. Following standard toxicity protocols, the nymphs were not fed during the 7 days exposure (ASTM, 2008). At day $7^{\text {th }}$ of exposure period, the numbers of dead and live nymphs were noted. The criterion for death was lack of response to prodding. During preliminary experiment, no mortality of nymphs occurred up to $50 \mathrm{ppm}$. Therefore, further experiments were performed using high concentrations. Therefore, nymphs of each species were exposed to higher concentrations $(100,200,400$ and $600 \mathrm{ppm})$ of $\mathrm{NH}_{4}{ }^{+}$solution for determining LC50 values. Five intact last instar nymphs of each species were placed individually in their respective five containers (four concentrations and one control). This experiment was run in triplicate. After 7 days of exposure, the number of dead and live nymphs was noted. Several trips were conducted for collection of nymphs and experiments were repeated continuously till the number of nymphs in each replica for each concentration reached 20. In total 20 independent experiments were conducted. 


\section{Sensitivity of odonate nymphs to nitrate}

Stock solution of $\mathrm{NO}_{3}{ }^{-}$was prepared by dissolving sodium nitrate $\left(\mathrm{NaNO}_{3}\right)$ in nonchlorinated tap water. The molecular weight of $\mathrm{NaNO}_{3}$ is $85.5 \mathrm{~g}$ which contains $62 \mathrm{~g}$ of $\mathrm{NO}_{3}{ }^{-} .1 .4 \mathrm{~g}$ of $\mathrm{NaNO}_{3}$ was required for preparation of $1000 \mathrm{ml} \mathrm{NO}{ }^{-}$solution of 1000 ppm. From this stock solution, testing solutions of different concentrations of $\mathrm{NO}_{3}{ }^{-}$were prepared by applying the dilution equation $\mathrm{C} 1 \mathrm{~V} 1=\mathrm{C} 2 \mathrm{~V} 2$.

According to the standards for wastewater reuse in the Eastern Mediterranean Region, the maximum permissible concentration of $\mathrm{NO}_{3}{ }^{-}$in effluents for reuse in agricultural irrigation is $45 \mathrm{ppm}$ (WHO, 2006). Therefore, during the present research, the minimum concentration of $\mathrm{NO}_{3}{ }^{-}$to which odonate nymphs were exposed was 45ppm. The concentrations of $\mathrm{NO}_{3}{ }^{-}$to which nymphs were exposed during range finding bioassay were $45,100,150,200,400 \mathrm{ppm}$. The rest of detail of range finding bioassay was the same as described for $\mathrm{NH}_{4}{ }^{+}$. During preliminary experiment no

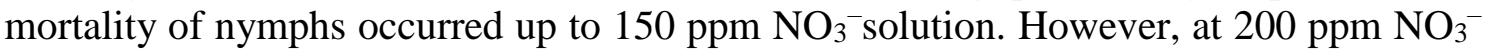
concentration, mortality in nymphs of each Odonate species was observed. Therefore, nymphs of each species were exposed to higher concentrations $(200,400,550$ and $700 \mathrm{ppm}$ ) of $\mathrm{NO}_{3}{ }^{-}$solution for determining LC50 values. The rest of detail of experiment for determining LC50 values are the same as described for $\mathrm{NH}_{4}{ }^{+}$.

\section{Statistical analysis}

The $24 \mathrm{~h}$ feeding rate of odonate nymphs were compared by applying Tukey test in One Way ANOVA. The difference in feeding rate of each odonate nymph species between light and dark phases was analyzed by Independent Samples t-Test. The effects of variation in predator density, water volume and prey density on daily feeding rate of each odonate nymph was analyzed by multiple linear regression test. During the study on sensitivity of odonate nymphs to inorganic nutrient pollutants, the average of percent mortality data was subjected to log probit analysis (Finney, 1971) for calculating LC S0. $_{50}$ SPSS 16 software was used for the analysis of the data. The $\mathrm{LC}_{50}$ values were compared by $95 \%$ confidence limits overlap method.

\section{Results}

\section{4-h feeding rate of donate nymphs during April, 2017}

During April 2017 experiments, the 24-h feeding rates of I. elegans, T. aurora and $P$. flavescens on $C x$. quinquefasciatus $3^{\text {rd }}$ instar larvae were studied in the laboratory (Table 2). Significantly higher $(\mathrm{P}>0.05)$ number of $C x$. quinquefasciatus $3^{\text {rd }}$ instar larvae were consumed by $P$. flavescens $(47.0 \pm 5.1$ larvae/24-h) followed by $T$. Aurora $(17.8 \pm 4.2$ larvae/24-h) and I. elegans $(10.5 \pm 3.1$ larvae/24-h).

\section{Feeding rate of odonate nymphs during light and dark phases in April, 2017}

During April 2017 study, the per hour feeding rates of I. elegans, T. aurora and P. flavescens on $3^{\text {rd }}$ instar larvae of $C x$. quinquefasciatus were compared between the daytime and night-time (Table 3). The nymphs of I. elegans species consumed $0.52 \pm$ 0.19 larvae /hour at the day time and $0.35 \pm 0.16$ larvae/hour at the night time. The difference in feeding rate between the day and night time was significant. Similar trend was also observed in $P$. flavescens. However, T. aurora showed insignificantly 
( $\mathrm{P}>0.05)$ higher feeding rate during the night time $(1.03 \pm 0.24$ larvae /hour) as compared to its feeding rate during the day time $(0.91 \pm 0.11$ larvae/hour $)$.

\section{4-h feeding rate of donate nymphs during September, 2017}

The 24-h feeding rates of L. fulva, S. decoloratum and C. servilia on Cx. quinquefasciatus $3^{\text {rd }}$ instar larvae were studied during September 2017 (Table 4). Maximum number of mosquito larvae was consumed by $S$. decoloratum (17.2 \pm 4.2 larvae/24 h) followed by L. fulva $(14.2 \pm 2.3$ larvae/24 h) and C. servilia $(11.8 \pm 2.1$ larvae/24 h). The difference in consumption rate between $S$. decoloratum and $C$. servilia was significant $(\mathrm{P}<0.05)$ but the difference between the $S$. decoloratum and L. fulva or L. fulva and C. servilia was not significant $(\mathrm{P}>0.05)$.

Feeding rate of odonate nymphs during light and dark phases in September, 2017

During September 2017 study, the 12-h feeding rates of L. fulva, S. decoloratum and C. servilia were compared between the day and night times (Table 5). The feeding rate of each of these odonate specie was significantly higher $(\mathrm{P}<0.05)$ during the daytime as compared to the night-time.

\section{Feeding pattern of odonate nymphs after every 3 interval}

The feeding pattern of nymphs of L. fulva, S. decoloratum and $C$. servilia were also noted after every $3 \mathrm{~h}$ interval at day and night times for $24 \mathrm{~h}$ (Fig. 2). Each nymph consumed maximum larvae during the first 3-h interval (6:00 to 9:00 $\mathrm{h}$ Pakistan standard time).

Table 2. 24-h feeding rate of odonate nymphs against $C x$. quinquefasciatus $3^{\text {rd }}$ instar larvae during April 2017 experiments

\begin{tabular}{c|c|c|c|c}
\hline \multirow{2}{*}{ Odonate Sp. } & \multirow{2}{*}{$\begin{array}{c}\text { No. of larvae consumed per } \\
\mathbf{2 4} \text { h (mean + Sd) }\end{array}$} & \multicolumn{2}{|c|}{$\mathbf{9 5 \%}$ confidence interval } & \multirow{2}{*}{ F value } \\
\cline { 3 - 5 } & $10.5 \pm 3.1^{\mathrm{c}}$ & Lower bound & Upper bound & \\
\hline I. elegans & $17.8 \pm 4.2^{\mathrm{b}}$ & 8.6 & 12.4 & 20.5 \\
T. aurora & $47.0 \pm 5.1^{\mathrm{a}}$ & 15.2 & 50.3 & 251.6 \\
P. flavescens & 43.7 & & \\
\hline
\end{tabular}

Different letters in superscript represent that the 24-h feeding rate of different odonate nymphs is significantly different at $\mathrm{P}<0.05$ (Tukey Test)

Table 3. Feeding rate of odonate nymphs during light and dark phases in April 2017

\begin{tabular}{c|c|c|c|c}
\hline Species & $\begin{array}{c}\text { No. of larvae consumed } \\
\text { per hour at day time } \\
\text { (mean + Sd) }\end{array}$ & $\begin{array}{c}\text { No. of larvae consumed } \\
\text { per hour at night time } \\
\text { (Mean + Sd) }\end{array}$ & T value & $\begin{array}{c}\text { Significance 2- } \\
\text { tailed }\end{array}$ \\
\hline I. elegans & $0.52+0.19^{*}$ & $0.35+0.16$ & 1.895 & $\mathrm{P}<0.05$ \\
T. aurora & $0.91+0.11$ & $1.03+0.24$ & -1.317 & $\mathrm{P}>0.05$ \\
P. flavescens & $2.2+0.5^{*}$ & $1.8+0.28$ & -2.7 & $\mathrm{P}<0.05$ \\
\hline
\end{tabular}

* represents that the hourly feeding rate of a nymph during the day time is significantly higher from the night time (independent sample T-test) 
Table 4. 24-h feeding rate of odonate nymphs against $C x$. quinquefasciatus $3^{\text {rd }}$ instar larvae during September 2017 experiments

\begin{tabular}{c|c|c|c|c}
\hline \multirow{2}{*}{ Odonate Sp. } & \multirow{2}{*}{$\begin{array}{c}\text { No. of larvae } \\
\text { consumed per 24-h } \\
\text { (mean + Sd) }\end{array}$} & \multicolumn{2}{|c|}{$\mathbf{9 5 \%}$ Confidence Interval } & \multirow{2}{*}{ F value } \\
\cline { 3 - 4 } & $14.2 \pm 2.3^{\mathrm{ab}}$ & 11.7 & 16.6 & \\
\hline L. fulva & $17.2 \pm 4.2^{\mathrm{b}}$ & 12.8 & 21.5 & \multirow{2}{*}{21.9} \\
S. decoloratum & $11.8 \pm 2.1^{\mathrm{a}}$ & 9.8 & 13.9 & \\
C. servilia & & & & \\
\hline
\end{tabular}

Different letters in superscript represent that the 24-h feeding rate of different odonate nymphs is significantly different at $\mathrm{P}<0.05$ (Tukey Test)

Table 5. Feeding rate of odonate nymphs during light and dark phases in September 2017

\begin{tabular}{c|c|c|c|c}
\hline Species & $\begin{array}{c}\text { No. of larvae consumed per } \\
\text { 12-h at day time (mean + }\end{array}$ & $\begin{array}{c}\text { No. of larvae consumed } \\
\text { per 12-h at night time } \\
\text { (mean + Sd) }\end{array}$ & T value & $\begin{array}{c}\text { Significance 2- } \\
\text { tailed }\end{array}$ \\
\hline L. fulva & $8.8 \pm 1.5^{*}$ & $5.3 \pm 1.03$ & 4.8 & $\mathrm{P}<0.05$ \\
S. decoloratum & $11.6 \pm 4.1^{*}$ & $5.5 \pm 1.04$ & 3.6 & $\mathrm{P}<0.05$ \\
C. servilia & $7.83 \pm 1.5^{*}$ & $4.0 \pm 0.89$ & -5.4 & $\mathrm{P}<0.05$ \\
\hline
\end{tabular}

* represents that the 12 -h feeding rate of a nymph during the day time is significantly higher from the night time (independent sample T-test)

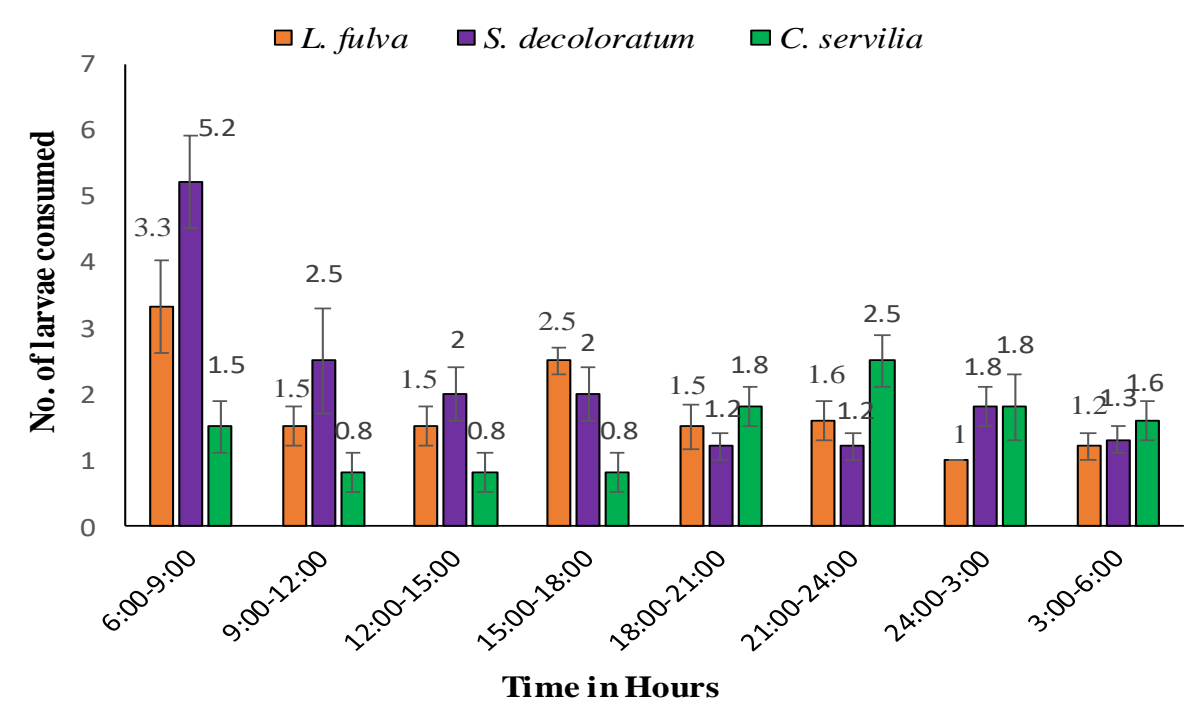

Figure 2. Feeding pattern of nymphs of three odonate species after every $3 \mathrm{~h}$ interval during light and dark phases for $24 \mathrm{~h}$

\section{Feeding rate under varied condition of predator density, water volume and prey density}

The 24-h feeding rate of I. elegans, T. aurora and P. flavescens on $3^{\text {rd }}$ instar larvae of $C x$. quinquefasciatus was also studied under varied conditions (combinations) of 
predator density, water volume and prey (mosquito larvae) density (Table 6). Nymph of each odonate species consumed significantly higher number $(\mathrm{P}<0.05)$ of mosquito larvae in combination no. 6 (condition of increased predator and prey density and decreased water volume) as compared to other combinations. In this combination, $I$. elegans, T. aurora and P. flavescens consumed $22.0 \pm 2.6,45.3 \pm 4.1$ and $63.0 \pm 7.5$ larvae/day (larvae consumed/24-h), respectively. Strong correlation (R square > 0.70) was observed during determination of correlation of feeding rate of each odonate species with variation in predator density, water volume and prey density. The regression equation for nymphs of each odonate species clearly indicated that the feeding rate is positively correlated with increase in prey and predator density but negatively correlated with increase in water volume.

\section{Sensitivity of predators of mosquito larvae to ammonium $\left(\mathrm{NH}_{4}^{+}\right)$}

During the present research, the sensitivity of I. elegans, T. aurora and P. flavescens was studied during exposure to various concentrations of $\mathrm{NH}_{4}{ }^{+}$for seven days (Table 7). During range finding study, the highest concentration of $\mathrm{NH}_{4}{ }^{+}$that caused no mortality of odonate nymphs was $50 \mathrm{ppm}$. The lowest concentration of $\mathrm{NH}_{4}{ }^{+}$that caused some mortality among the odonate nymphs was $100 \mathrm{ppm}$. At this concentration of $\mathrm{NH}_{4}{ }^{+}$, lowest mortality $(3.3 \pm 1.6 \%)$ was observed in P. flaviscans followed by $T$. aurora $(5.0 \pm 0 \%)$ and I. elegans $(6.6 \pm 1.6 \%)$. Similar trend was noted during exposure to highest concentration i.e., $600 \mathrm{ppm}$. At this concentration, the mean percent mortality of P. flaviscans, T. aurora and I. elegans were $43.3 \pm 1.6 \%, 58.3 \pm 7.2 \%$ and $71.6 \pm 1.6 \%$, respectively. Maximum $L_{50}$ value was shown by $P$. flaviscans $(740.3 \mathrm{ppm})$ followed by T. aurora $(516.7 \mathrm{ppm})$ and I. elegans $(425.7 \mathrm{ppm})$.

Table 6. Feeding rate of odonate nymphs on mosquito larvae under varied conditions of predator density, water volume and prey density

\begin{tabular}{|c|c|c|c|c|c|c|}
\hline Species & $\begin{array}{c}\text { S. No of } \\
\text { combinations }\end{array}$ & Combination & $\begin{array}{c}\text { Larvae } \\
\text { consumed } / 24 \mathrm{~h}\end{array}$ & $\begin{array}{c}\text { F } \\
\text { value }\end{array}$ & $\begin{array}{c}\mathbf{R}^{2} \\
\text { value }\end{array}$ & Y-equation \\
\hline \multirow{6}{*}{ 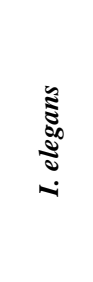 } & 1 & 1 predator, $1 \mathrm{~L}$ and 50 Prey & $10.3 \pm 2.1 b$ & \multirow{6}{*}{59.7} & \multirow{6}{*}{0.78} & \multirow{6}{*}{$\begin{array}{c}7.6+6.3 \text { (predator) }-7.16(\text { volume })+0.07 \\
(\text { prey })\end{array}$} \\
\hline & 2 & 1 predator, $2 \mathrm{~L}$ and 50 Prey & $5.0 \pm 1.7 \mathrm{a}$ & & & \\
\hline & 3 & 1 predator, 1 Land 100 Prey & $11.3 \pm 4.1 b$ & & & \\
\hline & 4 & 2 predators, $1 \mathrm{~L}$ and 50 Prey & $16.3 \pm 1.5 \mathrm{c}$ & & & \\
\hline & 5 & 2 predators, $2 \mathrm{~L}$ and 50 Prey & $7.3 \pm 4.1 b$ & & & \\
\hline & 6 & 2 predators, 1 Land 100 Prey & $22.0 \pm 2.6 \mathrm{~d}$ & & & \\
\hline \multirow{6}{*}{ 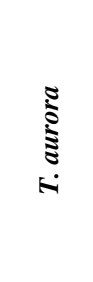 } & 1 & 1 predator, $1 \mathrm{~L}$ and 50 Prey & $20.6 \pm 4.1 \mathrm{a}$ & \multirow{6}{*}{80.9} & \multirow{6}{*}{0.77} & \multirow{6}{*}{$\begin{array}{c}0.6+20.2 \text { (predator) }-4.3(\text { volume })+0.05 \\
\text { (prey) }\end{array}$} \\
\hline & 2 & 1 predator, 2L and 50 Prey & $16.6 \pm 5.8 \mathrm{a}$ & & & \\
\hline & 3 & 1 predator, 1 Land 100 Prey & $18.6 \pm 3.2 \mathrm{a}$ & & & \\
\hline & 4 & 2 predators, $1 \mathrm{~L}$ and 50 Prey & $38.0 \pm 5.3 \mathrm{~d}$ & & & \\
\hline & 5 & 2 predators, $2 \mathrm{~L}$ and 50 Prey & $33.3 \pm 11.5 \mathrm{c}$ & & & \\
\hline & 6 & 2 predators, 1 Land 100 Prey & $45.3 \pm 4.1 \mathrm{e}$ & & & \\
\hline \multirow{6}{*}{ 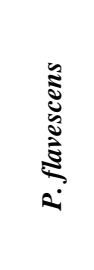 } & 1 & 1 predator, $1 \mathrm{~L}$ and 50 Prey & $38.6 \pm 10.1 \mathrm{a}$ & \multirow{6}{*}{55.8} & \multirow{6}{*}{0.73} & \multirow{6}{*}{$\begin{array}{c}18.3+21.1 \text { (predator) }-5.16(\mathrm{Vol})+0.06 \\
\text { (prey) }\end{array}$} \\
\hline & 2 & 1 predator, $2 \mathrm{~L}$ and 50 Prey & $32.3 \pm 6.8 \mathrm{a}$ & & & \\
\hline & 3 & 1 predator, 1 Land 100 Prey & $38.6 \pm 3.2 \mathrm{a}$ & & & \\
\hline & 4 & 2 predators, $1 \mathrm{~L}$ and 50 Prey & $57.0 \pm 7.0 \mathrm{c}$ & & & \\
\hline & 5 & 2 predators, $2 \mathrm{~L}$ and 50 Prey & $53.0 \pm 11.2 \mathrm{c}$ & & & \\
\hline & 6 & 2 predators, 1 Land 100 Prey & $63.0 \pm 7.5 \mathrm{~d}$ & & & \\
\hline
\end{tabular}

Means having different letters are significantly different at $\mathrm{P}<0.05$ (Tukey Test) 
Table 7. Sensitivity of nymphs of three different odonate species to ammonium $\left(\mathrm{NH}^{+}\right)$

\begin{tabular}{|c|c|c|c|c|c|c|c|}
\hline \multirow[b]{2}{*}{ Species } & \multicolumn{5}{|c|}{ Concentration $(\mathbf{p p m}) / \%$ mortality $($ mean $+\mathrm{SE})$} & \multirow{2}{*}{$\begin{array}{c}\mathbf{L C}_{50} \\
(\mathbf{p p m})\end{array}$} & \multirow{2}{*}{$\begin{array}{l}95 \% \\
\text { confidence } \\
\text { limits }\end{array}$} \\
\hline & $\begin{array}{c}\mathbf{5 0} \\
\text { ppm }\end{array}$ & $100 \mathrm{ppm}$ & 200 ppm & 400 ppm & $600 \mathrm{ppm}$ & & \\
\hline I. elegans & 0 & $6.6 \pm 1.6$ & $20.0 \pm 2.8$ & $38.3 \pm 4.4$ & $71.6 \pm 1.6$ & $425.7 \mathrm{a}$ & $369.1-507.2$ \\
\hline T. aurora & 0 & $5.0 \pm 0$ & $16.7 \pm 1.6$ & $36.7 \pm 4.4$ & $58.3 \pm 7.2$ & $516.7 \mathrm{~b}$ & $446.5-625.8$ \\
\hline P. flaviscans & 0 & $3.3 \pm 1.6$ & $10.0 \pm 2.9$ & $26.7 \pm 1.6$ & $43.3 \pm 1.6$ & $740.3 \mathrm{c}$ & $648.1-879.3$ \\
\hline
\end{tabular}

The alphabetical order of letters in column of $\mathrm{LC}_{50}$ is according to increasing $\mathrm{LC}_{50}$ values. $\mathrm{LC}_{50}$ values sharing no letter are significantly different

\section{Sensitivity of predators of mosquito larvae to nitrate $\left(\mathrm{NO}_{3}^{-}\right)$}

During the present research, the sensitivity of I. elegans, T. aurora and P. flavescens was studied during exposure to various concentrations of $\mathrm{NO}_{3}{ }^{-}$for seven days (Table 8). During range finding study, the highest concentration of $\mathrm{NO}_{3}{ }^{-}$that caused no mortality of odonate nymphs was $150 \mathrm{ppm}$. The lowest concentration of $\mathrm{NO}_{3}{ }^{-}$that caused some mortality among the odonate nymphs was $200 \mathrm{ppm}$. During exposure to this concentration of $\mathrm{NO}_{3}{ }^{-}$, minimum mortality $(5.0 \pm 0.0 \%)$ was observed in $P$. flaviscans followed by $T$. aurora $(10.0 \pm 0.0 \%)$ and I. elegans $(11.6 \pm 1.7 \%)$. Similar trend was noted during exposure to highest concentration i.e., $700 \mathrm{ppm}$. At highest concentration of $\mathrm{NO}_{3}{ }^{-}$, the mean percent mortality of $P$. flaviscans, $T$. aurora and I. elegans were 28.3 $\pm 1.6 \%, 50.0 \pm 5.8 \%$ and $65.0 \pm 2.7 \%$, respectively. Maximum $\mathrm{LC}_{50}$ value was shown by $P$. flaviscans $(\mathrm{LC} 50=1353.1 \mathrm{ppm})$ followed by $T$. aurora $\left(\mathrm{LC}_{50}=678.4 \mathrm{ppm}\right)$ and $I$. elegans $\left(\mathrm{LC}_{50}=597.8 \mathrm{ppm}\right)$.

Table 8. Sensitivity of nymphs of three different odonate species to nitrate $\left(\mathrm{NO}_{3}^{-}\right)$

\begin{tabular}{|c|c|c|c|c|c|c|c|}
\hline \multirow{2}{*}{ Species } & \multicolumn{5}{|c|}{ Concentration $(\mathrm{ppm}) / \%$ mortality $($ mean \pm SE) } & \multirow{2}{*}{$\mathbf{L C}_{50}(\mathbf{p p m})$} & \multirow{2}{*}{$\begin{array}{c}95 \% \text { confidence } \\
\text { limits }\end{array}$} \\
\hline & 150 & 200 & 400 & $\mathbf{5 5 0}$ & 700 & & \\
\hline & 0 & $1.6 \pm 1.7$ & $26.6 \pm 3.3$ & $40.0 \pm 2.8$ & $65.0 \pm 2.7$ & & $391.4-2595.6$ \\
\hline T. aurora & 0 & $10.0 \pm 0.0$ & $20.0 \pm 2.9$ & $28.3 \pm 4.4$ & $50.0 \pm 5.8$ & $678.4^{\mathrm{ab}}$ & 463.4-3167.3 \\
\hline P. flaviscans & 0 & $5.0 \pm 0.0$ & $10.0 \pm 0.0$ & $21.6 \pm 4.4$ & $28.3 \pm 1.6$ & $1353.1^{\mathrm{abc}}$ & $969.1-4338.3$ \\
\hline
\end{tabular}

The alphabetical order of letters in column of $\mathrm{LC}_{50}$ is according to increasing $\mathrm{LC}_{50}$ values. $\mathrm{LC}_{50}$ values sharing no letter are significantly different

\section{Discussion}

For the control of mosquitoes and other insect pests, alternative approaches that are ecofriendly should be adopted (Ghosh et al., 2012). Biological control strategies are environment friendly, sustainable and targeting a range of different mosquito species which help in reduction of reliance on application of synthetic chemical insecticides (Benelli et al., 2016). Historically, Biological control involves the application of natural predators which is particularly important for the control of mosquito-borne arboviruses, which normally do not have specific antiviral therapies available (Huang et al., 2017). Damselfly and dragonfly nymphs have the predatory ability and share aquatic habitat with the immature stages of mosquitoes therefore they can be considered good biological control agents against mosquitoes (Mitra, 2006; Chatterjee et al., 2007). During the present research, the predatory efficiencies of nymphs of six coexisting 
odonate species i.e., I. elegans, T. aurora, P. flavescens, L. fulva, S. decoloratum and $C$. servilia were studied by using $C x$. quinquefasciatus $3^{\text {rd }}$ instar larvae as prey. There was observed variation in the daily (24-h) feeding rate of nymphs of various odonate species (Tables 2 and 4). Highest number of mosquito larvae was ingested by the $P$. flavescens nymph (47.0 \pm 5.1 mosquito larvae/day). To the best of author knowledge, the predatory ability of $T$. aurora, P. Flavescens, L. fulva, S. decoloratum and C. servilia nymphs have been studied for the first time during the present study. The predation performance of few other odonate nymph species have been reported. For example, Miura and Takahashi (1988) studied the predatory ability of damselfly nymph, Enallagma civile, against the Culex torsalis larvae. The average $24 \mathrm{~h}$ feeding rate of last instar nymph of E. civile on 3rd instar larvae of Cx. tarsalis was 6.06 larvae. Mandal et al. (2008) studied the predatory efficiency of nymphs of two dragonfly species i.e., Aeshna flavifrons and Sympetrum durum, and three damselfly species i.e., Coenagrion kashmirum, Ischnura forcipata and Rhinocypha ignipennis, against $4^{\text {th }}$ instar larvae of $C x$. quinquefasciatus. I. forcipata nymph consumed highest number of mosquito larvae (64.3 \pm 1.8$)$. Akram and Ali-Khan (2016) studied the predation performance of five odonate nymphs, Anax parthenope, Bradinopyga geminate, Ischnura forcipata, Rhinocypha quadrimaculata and Trithemis aurora against the $4^{\text {th }}$ instar larvae of Aedes aegypti in the laboratory. Ischnura forcipata consumed highest number of mosquito larvae (56 larvae/ day). Chandra et al. (2006) studied the predatory efficiency of a dragonfly nymph, Brachytron pratense, against the larvae of Anopheles subpictus in the laboratory conditions. Brachytron pretense consumed up to 66 mosquito larvae through $24 \mathrm{~h}$. The predatory ability of odonate nyphs against non inscet pests have also been studied. For example, Younes et al. (2016) studied the predation performance of odonate nymphs of the species Hemianax ephippiger against two species of fresh water snail, Bulinus truncatus and Biomphalaria alexandrina which act as intermediate hosts of Schistosoma species. Odonata nymph consumed both species of the fresh water snail, however the odonate nymphs consumed more Bulinus truncatus than Biomphalaria alexandrina. Consumption rate also differed according to the snail type, density and size. Odonate nymphs preferred small sized prey.

The predation performance of nymphs of different odonate species was also compared between the day and night times. During the April 2017 study, the per hour feeding rates of $I$. elegans, T. aurora and P. flavescens on $3^{\text {rd }}$ instar larvae of $C x$. quinquefasciatus were compared between the day and night times. The nymphs of $I$. elegans and P. flavescens species consumed significantly higher $(\mathrm{P} \leq 0.05)$ number of mosquito larvae during the day time as compared to the night time. The feeding rate of T. aurora was also higher during the day time but the difference from the night time was insignificant $(\mathrm{P}>0.05)$ (Table 3). During the September 2017 study, the 12-h feeding rates of $L$. fulva, S. decoloratum and $C$. servilia on $3^{\text {rd }}$ instar larvae of $C x$. quinquefasciatus were compared between the day and night times. Each nymph consumed maximum larvae during the first 3-h interval (6:00 to 9:00 $\mathrm{h}$ Pakistan standard time). Similar trend has also been reported by Venkatesh and Tyagi (2013) during their study on the predatory performance of Bradinopyga geminata and Ceriagrion coromandelianum larvae on Aedes aegypti larvae in the laboratory conditions. During the present study, the duration of the day and night time was $12 \mathrm{~h}$ each. Therefore, the feeding rate of nymphs of L. fulva, S. decoloratum and C. servilia was compared between the day and night times (Table 5). Nymphs of all these odonate species consumed significantly higher number of mosquito larvae during the day time 
as compared to the night time ( $\mathrm{P}<0.05)$. Mandal et al. (2008) reported higher feeding rate of different odonate nymph species at the light phase as compared to the dark phase. A dragonfly nymph, Brachytron pretense consumed more Anopheles subpictus larvae during the day time compared to the night time (Chandra et al., 2006). Chandra et al. (2008) reported that feeding rate of A. sulcatus did not differ between the light and dark phases. Eyes in odonate nymphs are known to be very helpful in capturing prey but mechanoreceptors also play equal role in predation (Mandal et al., 2008). Backswimmers use both mechanoreceptor and vision for detecting their prey (Dieguez and Gilbert, 2003). Mechanoreceptors play role in detecting waves and providing accurate information for discriminating between prey and non-prey vibrations and adjusting their orientation or displaying prey catching behavior (Lang, 1980). In several odonate species, the nymphs come out from perches at night and wander for predation (Corbet, 1980). Dieguez and Gilbert (2003) studied the effect of light and dark on the predation efficiency of Backswimmer, Buenoa macrotibialis. It was noted that Buenoa macrotibialis can feed on small prey such as Brachionus calyciflorus and Tropocyclops extensus in presence of light but cannot feed well on these small preys in dark. It was further noted that Buenoa macrotibialis can feed equally in light and dark conditions on the largest prey such as Daphnia pulex. Their findings show the importance of both visual and mechanical cues in detecting prey of different sizes.

The 24-h feeding rate of I. elegans, T. aurora and P. flavescens on $3^{\text {rd }}$ instar larvae of $C x$. quinquefasciatus was also studied under varied conditions of predator density, water volume and prey (mosquito larvae) density (Table 6 ). The feeding rate of nymphs of each odonate species was positively correlated with increase in density of predator and prey but negatively correlated with increase in volume of water. This showed that the independent variables i.e., predator density, water volume and prey density are strong predictors of feeding rate of odonate nymphs on mosquito larvae. The negative impact of increased water volume (search area) on the feeding rate of odonate nymphs on mosquito larvae may be probably due to the evasion tactics of the mosquito larvae (Bhattacharjee et al., 2009). The positive correlation of increase in predator density with increase in predation rate on mosquito larvae may be probably due to intra-specific completion (Chandra et al., 2006). The positive correlation of increase in prey density with increase in predation rate of odonate nymphs on mosquito may be probably due to increase in chances of availability of prey to the odonate nymphs. Similar results have also been reported by other researchers in other odonate nymph species or other predatory insects against mosquito larvae. For example, Chandra et al. (2006) observed a decrease in the feeding rate of a dragonfly nymph (Brachytron pratense) on Anopheles subpictus larvae with increase in water volume. On the other hand, there occurred an increase in feeding rate of Brachytron pretense nymph on Anopheles subpictus larvae with increase in predator and prey (mosquito larvae) density. Mandal et al. (2008) studied variation in feeding rate of nymphs of five odonate species on $4^{\text {th }}$ instar larvae of Culex quinquefasciatus (as prey) with variation in predator density, water volume (search area) and prey density. The predation rate was negatively correlated with increases in water volume (increase in search area) but linearly related to the increase in the density of predator and density. In the study of Chandra et al. (2008), the feeding rate of Acilius sulcatus larvae (predator) on the $4^{\text {th }}$ instar larvae of Culex quinquefasciatus (prey) decreased with increase in water volume but increased with increase in the density of prey and predators. 
During the present research, I. elegans, T. aurora and $P$. flavescens nymphs were exposed to various concentrations of $\mathrm{NH}_{4}{ }^{+}$and $\mathrm{NO}_{3}{ }^{-}$for seven days for testing their sensitivity to these pollutants. Nymphs of all the species survived up to $50 \mathrm{ppm}$ concentration of $\mathrm{NH}_{4}{ }^{+}$. Nymphs of $P$. flavescens were found less sensitive to $\mathrm{NH}_{4}{ }^{+}$. The $\mathrm{LC}_{50}$ value of $\mathrm{NH}_{4}{ }^{+}$for $P$. flavescens was significantly higher when compared to the $\mathrm{LC}_{50}$ values of $\mathrm{NH}_{4}{ }^{+}$for T. aurora and I. elegans (Table 7). To the author knowledge there are no reports about the toxicity of $\mathrm{NH}_{4}{ }^{+}$or ammonia $\left(\mathrm{NH}_{3}\right)$ with I. elegans, $T$. aurora and $P$. flavescens nymphs. However, $\mathrm{NH}_{3}$ toxicity with other odonate nymphs such as Erythromma najas, Lestes sponsa and Sympetrum flaveolum has been reported by Beketov (2002). These nymphs showed high tolerance to $\mathrm{NH}_{3}$. Toxicity of $\mathrm{NH}_{4}{ }^{+}$is dependent on $\mathrm{pH}$ (Körner et al., 2001). Both, un-ionized $\left(\mathrm{NH}_{3}\right)$ and ionized $\left(\mathrm{NH}_{4}^{+}\right)$ forms of ammonia may exist in aqueous solution. The ratio of $\mathrm{NH}_{3}$ to $\mathrm{NH}_{4}{ }^{+}$increases with rise in $\mathrm{pH}$ and temperature (Körner et al., 2001). Uncharged ammonia $\left(\mathrm{NH}_{3}\right)$ can cross biological membrane more easily than charged $\mathrm{NH}_{4}{ }^{+}$, therefore $\mathrm{NH}_{3}$ is more toxic (Levit, 2010). The toxic effects of $\mathrm{NH}_{3}$ to aquatic invertebrate is mediated by damaging the respiratory surfaces and changing the $\mathrm{pH}$ of hemolymph (Colt and Armstrong, 1981). $\mathrm{NH}_{4}{ }^{+}$become toxic at higher concentration (Monselise and Kost, 1993). During the present study, solutions of $\mathrm{NH}_{4} \mathrm{Cl}$ were prepared in non-chlorinated tap water with neutral $\mathrm{pH}(\mathrm{pH} 7.3)$ and experiment was conducted at room temperature (17 to $23^{\circ} \mathrm{C}$ ), thus the existence of $\mathrm{NH}_{3}$ would be less likely. Martinelle and Häggström (1993) presented a model that explains the mechanism of $\mathrm{NH}^{+}$toxicity. According to the model, $\mathrm{NH}_{4}{ }^{+}$competes with potassium ions for inward transport over the cell membrane through potassium transport proteins such as $\mathrm{Na}^{+} / \mathrm{K}^{+}$-ATPase and the $\mathrm{Na}^{+} / \mathrm{K}^{+}-2\left(\mathrm{Cl}^{-}\right)-\mathrm{co}^{-}$ transporter. It was concluded that one important toxic effect of $\mathrm{NH}_{4}^{+}$is the need for maintaining ion gradients across the membrane that require energy.

During the study of susceptibility of I. elegans, O. sabina and P. flavescens nymphs to different concentrations of $\mathrm{NO}_{3}{ }^{-}$, all the nymphs survived up to $150 \mathrm{ppm}$ concentration of $\mathrm{NO}_{3}{ }^{-}$(Table 8). However, exposure to higher $\mathrm{NO}_{3}{ }^{-}$concentrations resulted in mortality. Nymphs of $P$. flavescens were found least susceptible to $\mathrm{NO}_{3}{ }^{-}$. For example, maximum LC $\mathrm{C}_{50}$ value was shown by $P$. flaviscans $(1353.1 \mathrm{ppm})$ followed by O. sabina $(678.4 \mathrm{ppm})$ and I. elegans $(597.8 \mathrm{ppm})$. During the present research, the $\mathrm{LC}_{50}$ values of $\mathrm{NO}_{3}^{-}$against odonate nymphs were higher than the $\mathrm{LC}_{50}$ values of ammonium against these nymphs. This might be explained by the fact that biological membranes are less permeable to $\mathrm{NO}_{3}{ }^{-}$than to $\mathrm{NH}_{4}{ }^{+}$, therefore there occurs limited uptake of $\mathrm{NO}_{3}{ }^{-}$in aquatic animals, which contribute to relatively low toxicity of $\mathrm{NO}_{3}{ }^{-}$ (Cheng and Chen, 2002; Alonso and Camargo, 2003). The main toxic action of $\mathrm{NO}_{3}{ }^{-}$on aquatic animals is due to the conversion of oxygen-carrying pigments (e.g., hemoglobin, hemocyanin) to forms that are incapable of carrying oxygen (e.g., methemoglobin) (Scott and Crunkilton, 2000; Cheng and Chen, 2002).

To the author knowledge there are no reports about the toxicity of $\mathrm{NO}_{3}{ }^{-}$with the odonate nymphs. However, $\mathrm{NO}_{3}{ }^{-}$toxicity with other aquatic invertebrates has been reported. For example, Alonso and Camargo (2003) studied short-term toxicity of ammonia, nitrite, and $\mathrm{NO}_{3}^{-}$to the aquatic snail, Potamopyrgus antipodarum (Hydrobiidae, Mollusca). The 4 days $\mathrm{LC}_{50}$ values of $\mathrm{NO}_{3}{ }^{-}$for $P$. antipodarum was 1042 ppm. Camargo et al. (2005) studied $\mathrm{NO}_{3}{ }^{-}$toxicity to two freshwater Amphipod species, Eulimnogammarus toletanus and Echinogammarus echinosetosus and a caddisfly (Hydropsyche exocellata). The 5 days $\mathrm{LC}_{50}$ of $\mathrm{NO}_{3}{ }^{-}$for E. toletanus, E. echinosetosus and $H$. exocellata were $73.1 \mathrm{ppm}, 56.2 \mathrm{ppm}$ and $230.2 \mathrm{ppm}$, respectively. 
The $\mathrm{LC}_{50}$ values of $\mathrm{NO}_{3}{ }^{-}$reported by Camargo et al. (2005) for E. toletanus, E. echinosetosus and $H$. exocellata are much lower than the $\mathrm{LC}_{50}$ values of $\mathrm{NO}_{3}{ }^{-}$for Odonate nymphs observed during the present research. The $\mathrm{LC}_{50}$ values of $\mathrm{NO}_{3}{ }^{-}$ reported by Alonso and Camargo (2003) for P. antipodarum are comparable to the $\mathrm{LC}_{50}$ values of $\mathrm{NO}_{3}{ }^{-}$observed during the present research for odonate nymphs. The toxicity of $\mathrm{NO}_{3}{ }^{-}$may decrease with increase in body size, water salinity, and environmental adaptation (Camargo et al., 2005). The effects of other environmental pollutants on aquatic insects have also been reported. For example, Lacerda et al. (2014) exposed Chironomus kiiensis lar larvae of Chironomus kiiensis larvae to crude oil. During their study, the 48-h LC $_{50}$ was $26.5 \mathrm{ppm}$. Maximum mortality for most of the tested concentrations was observed during the first $24 \mathrm{~h}$ of the experiment. Similarly, Miles et al. (2017), exposed predatory insects to different concentrations of clothianidin, a neonicotinoid, in a semi-natural mesocosm. They observed high mortality of predatory invertebrates and increasing prey density with increase in clothianidin concentration.

\section{Conclusion}

1) From the findings of the study of predatory ability of damselfly and dragonfly nymphs, it was concluded that I. elegans, T. aurora, P. flavescens, L. fulva, $S$. decoloratum and $C$. servilia nymphs can play an important role in the eco-friendly control of the $C x$. quinquefasciatus mosquito, and $P$. flavescens nymph is more efficient predator of $C x$. quinquefasciatus $3^{\text {rd }}$ instar larvae.

2) From the findings of the study of sensitivity of odonate nymphs to inorganic nutrient pollutants, it was concluded that I. elegans, T. aurora and $P$. flavescens nymphs can tolerate high concentration of $\mathrm{NH}_{4}{ }^{+}$, and $\mathrm{NO}_{3}{ }^{-}$under condition of neutral $\mathrm{pH}$ and room temperature. P. flavescens species is highly resistant to increasing water level of $\mathrm{NH}_{4}{ }^{+}$and $\mathrm{NO}_{3}$.

Authors contribution and Acknowledgements. This article has been prepared from the first author's (Ikram Ilahi) $\mathrm{PhD}$ thesis entitled "Ecofriendly control of Culex quinquefasciatus (Say, 1823) and susceptibility of its larvae and predators to different environmental pollutants" at the Department of Zoology, Islamia College, Peshawar, Khyber Pakhtunkhwa, Pakistan. Ali Muhammad Yousafzay acted as the supervisor. The remaining authors participated during collection in fields and/or in statistical analysis of data and preparation of manuscript. The help of Dr. Ahmad Zia, Senior Scientific Officer and Taxonomist in the Insect National Museum at National Agricultural Research Council (NARC), Islamabad, Pakistan, in providing literature and unpublished documents for identification of odonate nymphs is highly acknowledged.

\section{REFERENCES}

[1] Ajaegbu, E. A., Danga, S. P. Y., Chijoke, I. K., Okoye, F. B. C. (2016): Mosquito adulticidal activity of the leaf extracts of Spondias mombin L. against Aedes aegypti L. and isolation of active principles. - J. Vector Borne Dis. 53: 17-22.

[2] Akram, W., Ali-Khan, H. A. (2016): Odonate nymphs: generalist predators and their potential in the management of dengue mosquito, Aedes aegypti (Diptera: Culicidae). - J. Arthropod-Borne Dis. 10(2): 252-257.

[3] Alonso, A., Camargo, J. A. (2003): Short-term toxicity of ammonia, nitrite, and nitrate to the aquatic snail Potamopyrgus antipodarum (Hydrobiidae, Mollusca). - Bull. Environ. Contam. Toxicol. 70: 1006-1012. 
[4] Anjum, S. A. (1997): Biosystematics of odonate naiads of the Punjab by rearing techniques. - MSc Thesis, Department of Agriculture Entomology University of Agriculture Faisalabad, Pakistan.

[5] ASTM - American Society for Testing and Materials (2008): Guide for Conducting Acute Toxicity Tests on Aqueous Ambient Samples and Effluents with Fishes, Macroinvertebrates, and Amphibians. - ASTM International, West Conshohocken, Pennsylvania.

[6] Beketov, M. A. (2002): Ammonia toxicity to larvae of Erythromma najas (Hansemann), Lestes sponsa (Hansemann) and Sympetrum flaveolum (Linnaeus) (Zygoptera: Coenagrionidae, Lestidae; Anisoptera: Libellulidae). - Odonatologica 31(3): 297-304.

[7] Benelli, G., Jeffries, C. L., Walker, T. (2016): Biological control of mosquito vectors: past, present, and future. - Insects 7: 52 .

[8] Bhattacharjee, I., Aditya, G., Chandra, G. (2009): Laboratory and field assessment of thepotential of larvivorous, air-breathingfishes as predators of culicine mosquitoes. Biol. Control. 49: 126-133.

[9] Boyd, S. (2005): Damselflies and Dragonflies. Scientific Illustration Major. - University of Georgia, Athens. http://www.discoverlife.org/nh/tx/Insecta/Odonata/.

[10] Camargo, J. A., Alonso, A., Salamanca, A. (2005): Nitrate toxicity to aquatic animals: a review with new data for freshwater invertebrates. - Chemosphere 58: 1255-1267.

[11] Chandra, G., Chatterjee, S. N., Ghosh, A. (2006): Role of dragonfly (Brachytron pratense) nymph as a biocontrol agent of larval mosquitoes. - Bul. Penel Kesehatan 34(4): 147-151.

[12] Chandra, G., Bhattacharjee, I., Chatterjee, S. N., Ghosh, A. (2008): Mosquito control by larvivorous fish. - Indian J Med Res. 127: 13-27.

[13] Chatterjee, S. N., Ghosh, A., Chandra, G. (2007): Eco-friendly control of mosquito larvae by Brachytron pratense nymph. - J Environ Health 69(8): 44-49.

[14] Cheng, S. Y., Chen, J. C. (2002): Study on the oxyhemocyanin, deoxyhemocyanin, oxygen affinity and acid-base balance of Marsupenaeus japonicus following exposure to combined elevated nitrite and nitrate. - Aquatic Toxicol. 61: 181-193.

[15] Clark, T. E., Samways, M. J. (1996): Dragonflies (Odonata) as indicators of biotope quality in the Kruger National Park, South Africa. - J. Appl. Ecol. 33: 1001-1012.

[16] Colt, J. E., Armstrong, D. A. (1981): Nitrogen toxicity to crustaceans, fish and molluscs. - Bio-Engineering Symposium for FishCulture (FCS Publ.1), pp 34-47.

[17] Corbet, P. S. (1980): Biology of Odonata. - Ann Rev Entomol. 25: 189-218.

[18] Das, B. P., Deobhankar, K., Pohekar, K. N., Marathe, R., Husain, S. A., Jambulingam, P. (2016): Laboratory bioassay of Chilodonella uncinata, an entomopathogenic protozoan, against mosquito larvae. - Journal of Mosquito Research 6(10): 1-10.

[19] Dieguez, M. C., Gilbert, J. J. (2003): Predation by Buenoa macrotibialis (Insecta, Hemiptera) on zooplankton: effect of light on selection and consumption of prey. - J. Plankton Res. 25(7): 759-769.

[20] Dida, G. O., Gelder, F. B., Anyona, D. N., Abuom, P. O., Onyuka, J. O., Matano, A., Adoka, S. O., Kanangire, C. K., Owuor, P. O., Ouma, C., Ofulla, A. V. (2015): Presence and distribution of mosquito larvae predators and factors influencing their abundance along the Mara River, Kenya and Tanzania. - Springer plus 4: 136.

[21] Din, A. U., Zia, A., Bhatti, A. R., Khan, M. N. (2013): Odonata naiads of Potohar Plateau, Punjab, Pakistan. - Pakistan J. Zool. 45: 695-700.

[22] Du, Y., Ma, T., Deng, Y., Shen, S., Lu, Z. (2017): Sources and fate of high levels of ammonium insurface water and shallow groundwater of the Jianghan Plain, Central China. - Environ. Sci. Process Impacts 19: 161.

[23] Finney, D. J. (1971): Probit Analysis. - Cambridge University Press, London, pp 68-78.

[24] Gardner, A. E. (1960): A Key to the Larvae of the British Odonata. The New Naturalist Dragonflies. - Collins St. James, London, pp. 190-225. 
[25] Ghosh, A., Chowdhury, N., Chandra, G. (2012): Plant extracts as potential mosquito larvicides. - Indian J. Med. Res. 135(5): 581-598.

[26] Harbach, R. E. (1988): The mosquitoes of the subgenus Culex in South West Asia and Egypt (Diptera: Culicidae). - Contribution of American Entomological Institute 24(1).

[27] Hardersen. S., Wratten. S. D. (1996): The sensitivity of the nymphs of two New Zealand Damselfly Species (Odonata: Zygoptera) to Azinphos-Methyl and Carbaryl. - Australian Journal of Ecotoxicology 2: 55-60.

[28] Hickey, C. W., Vickers, M. L. (1994): Toxicity of Ammonia to Nine Native New Zealand freshwater Invertebrate Species. - Arch. Environ. Contain. Toxicol. 26: 292-298.

[29] Huang, Y. S., Higgs, S., Vanlandingham, D. L. (2017): Biological Control Strategies for Mosquito Vectors of Arboviruses. - Insects 8: 21.

[30] Knight. T. M., Chase, J. M., Goss, C. M., Knight, J. J. (2004): Effects of interspecific competition, predation, and their interaction on survival and development time of immature Anopheles quadrimaculatus. - J. Vector Ecol. 29: 277-284.

[31] Körner, S., Das, S. K., Veenstra, S., Vermaat, J. E. (2001): The effect of pH variation at theammonium/ammonia equilibrium in wastewaterand its toxicity to Lemna gibba. Aquat. Bot. 71: 71-78.

[32] Kumar, R., Hwang, J. S. (2006): Larvicidal efficiency of aquatic predators: a perspective for mosquito biocontrol. - Zool. Stud. 45(4): 447-466.

[33] Lacerda, A. C. F., Gusmão, G. A., Hamada, N. (2014): Tests of chronic and acute toxicity of crude oil on larvae of Chironomus kiiensis Tokunaga (Diptera: Chironomidae). - Braz. J. Biol. 74(3): S70-S77.

[34] Lang, H. H. (1980): Surface wave discrimination between prey and non-prey by the backswimmer Notonecta glauca L. (Hemiptera: Heteroptera). - Behav. Ecol. Sociobiol. 6: 233-246.

[35] Lee, S. E., Kim, J. E., Lee, H. S. (2001): Insecticide resistance in increasing interest. Agric. Chem. Biotechnol. 44: 105-112.

[36] Levit, S. M. (2010): A Literature Review of Effects of Ammonia on Fish. - The Nature Conservancy, Montana. pp 1-10.

[37] Lundkvist, E., Landin, J., Jackson, M., Svensson, C. (2003): Diving beetles (Dytiscidae) as predators of mosquito larvae (Culicidae) in field experiments and in laboratory tests of prey preference. - Bull. Entomol. Re. 93: 219-226.

[38] Mandal, S. K., Ghosh, A., Bhattacharjee, I., Chandra, G. (2008): Biocontrol efficiency of odonate nymphs against larvae of the mosquito, Culex quinquefasciatus Say, 1823. Acta. Trop. 106: 109-114.

[39] Martinelle, K., Häggström, L. (1993): Mechanisms of ammonia and ammonium ion toxicity in animal cells: transport across cell membranes. - J. Biotechnol. 30(3): 339-50.

[40] Miles, J. C., Hua, J., Sepulveda, M. S., Krupke, C. H., Hoverman, J. T. (2017): Effects of clothianidin on aquatic communities: Evaluating the impacts of lethal and sublethal exposure to neonicotinoids. - PLoS One 12(3): e0174171.

[41] Mitra, A. (2006): Current status of the Odonata of Bhutan: a checklist with four new records. - Bhu. J. RNR. 2(1): 136-143.

[42] Mitra, T. R. (2002): Geographical distribution of Odonate (Insecta) of Eastern India. Memoirs Zool. Survey India 19(1): 1-171.

[43] Monselise, B. E., Kost, D. (1993): Different ammonium uptake, metabolism and detoxification efficiencies in two Lemnaceae. - Planta 189: 167-173.

[44] Phillips, R. S. (2001): Current status of malaria and potential for control. - Cim. Microbial Rev. 14(1): 208-226.

[45] Rabalais, N. N. (2002): Nitrogen in aquatic ecosystems. - Ambio. 31: 102-112.

[46] Saha, N., Aditya, G., Saha, G. K. (2007a): A comparative study of predation of three aquatic heteropteran bugs on Culex quinquefasciatus larvae. - Limnology 8: 73-80. 
[47] Scott, G., Crunkilton, R. L. (2000): Acute and chronic toxicity of nitrate to fathead minnows (Pimephales promelas), Ceriodaphnia dubia and Daphnia magna. - Environ. Toxicol. Chem. 19: 2918-2922.

[48] Stav, G., Blaustein, L., Margalit, Y. (2005): Individual and interactive effects of a predator and controphic species on mosquito populations. - Ecol. Appl. 15(2): 587-598.

[49] US EPA-United States Environmental Protection Agency (1996): Ecological Effects Test Guidelines: Aquatic Invertebrate Acute Toxicity Test, Freshwater Daphnids. - US EPA, Washington, DC, pp. 712C-96-114.

[50] Venkatesh, A., Tyagi, B. K. (2013): Predatory potential of Bradinopyga geminate and Ceriagrion coromandelianum Larvae on dengue vector, Aedes aegypti under controlled conditions (Anisoptera: Libellulidae; Zygoptera: Coenagrionidae; Diptera: Culicidae). Odonatologica 42(2): 139-149.

[51] Walton, W. E. (2007): Larvivorous fish including Gambusia. - J. Amer. Mosq. Cont. Assoc. 23(sp2): 184-220.

[52] Wetzel, R. G. (2001): Limnology. 3rd Ed. - Academic Press, New York.

[53] WHO (2006): A Compendium of Standards for Wastewater Reuse in the Eastern Mediterranean Region. - WHO, Geneva.

[54] Yousuf, M., Khan, M. J., Khaliq, A. (1996): Description of some final instar naiads (Libellulidae: Odonata) from Punjab and Sindh. - Pak. Entomol. 18(1-2): 17-23.

[55] Zia, A. (2010): Biosystematics of damselflies (Zygoptera: Odonata) of Pakistan. - Ph.D. Thesis, Department of Agriculture Entomology, Pir Mehr Ali Shah Arid Agriculture University, Rawalpindi, Pakistan. 